\title{
Teaching and Learning English as a Second Language in Nigeria: Examining Evolving Approaches and Methods
}

\author{
Adebola Adebileje \\ Department of English, Redeemer's University, Nigeria \\ Aderonke Akinola \\ Department of English, Redeemer's University, Nigeria
}

\begin{abstract}
This paper examines language teaching and learning theories in a bid to consider evolving and appropriate approaches and methods for efficient teaching and learning English as a second language in Nigeria. While traditional approaches do provide a solid foundation for effective language teaching, they do not always address students' situational and current needs. Hence, the study reveals that strategies and methods are evolving especially, in this hi-tech age, to meet such additional needs. Since no one theory or method is the best, the study recommends a principled eclectic approach for the effective and functional teaching and learning of English in Nigeria. It also suggests processes that could enhance teaching and motivate learning in the ESL classroom.
\end{abstract}

Index Terms - language teaching theories, language learning theories, English as a second language (ESL), methods, and approaches

\section{INTRODUCTION}

Language is an instrument of thought which binds human society together in communities and linguistic groups. Linguists in different ages have variously defined it; Sapir (1921) sees it as a purely human and non-instinctive method of communicating ideas, emotions, and desires utilizing voluntarily produced symbols. To Asiyanbola (2012), language is "a human vocal noise or the graphic representation of that noise used systematically and conventionally by a group of people in a community." Therefore, language is solely a personal property. Crystal (2010) asserts that language belongs to everyone; hence, the diverse views about it. Although several studies (e.g., Akindele \& Adegbite, 2009; Banjo, 2016) have been carried out on the subject of English as a second language in Nigeria, little attention has been accorded to teaching and learning processes for the English language in Nigeria. It is on this premise that the present study attempts to examine different theories of language teaching and learning, in a bid to identify appropriate teaching and learning processes for the English language in Nigeria.

Although the advent of English in Nigeria was not ascertained, several studies (e.g., Kachru, 1995; Gut, 2004) had, however, suggested that harmonious business relationship had existed between Nigeria and Europe in the $16^{\text {th }}$ century as they traded in, particularly, ivory and slaves. Records show that the initiation and retention of English as the language of communication in Nigeria could be traced to some historical periods - the Industrial Revolution that started in 1750, the era of missionaries in 1846, the abolition of Slave Trade in 1883 and the outcome of Berlin Conference of 1884 and 1885 (Adetugbo, 1984; Awonusi, 2009). Presently, Nigeria has been said to be the third-largest speakers of English in the globe aside from India and the United States of America (Ethnologue, 2009). A total number of $79,000,000$ of Nigerian population speak English, while the number of L1 speakers is estimated at 4,000,000. English in Nigeria performs the role of language of education, instruction, educational evaluation, the media, government, politics and law and legal documents, and so on. It, therefore, becomes pertinent to focus on the processes of teaching and learning the English language in Nigeria.

The question is, how is a language learned? Several studies (Crystal (2010); Krashen (1987); Skinner (1957); Wilkins (1972)) have revealed that learning a language, especially a second language, effectively is premised on language teaching and learning theories.

\section{THEORIES OF SECOND LANGUAGE LEARNING}

Communication, as the key to knowledge, has always been important for individuals desiring to learn more about the world they live in and to be "able to access and use information in a number of languages," especially, English. This section focuses on the theories of second language (L2) learning in relation to the approaches to L2 acquisition theories propounded by Skinner (1957), Chomsky (1959), and other views that emerged afterward. Every approach to language revolves around the theories of language (Xia, 2014), which include: behaviouristic and cognitive theories. The two 
primary methods attempt to offer ideas on how a language can be learned or acquired.

\section{A. Behaviourist Theory}

Behaviouristic or imitation or reinforcement theory was proposed by Skinner in 1957 and prevailed between the 1920s and 1960s. Behaviourists patterned the language learning process after Pavlov's idea of conditioning, which centres on three procedural stages of stimulus, response, and reinforcement. Essentially, the theory suggests that learners become proficient in the usage of a language, like a mother tongue, by consistently imitating his/her teacher and constant practice followed by positive reinforcement (rewards) from the teacher (Bell, 1981, p. 24). However, there is more to language learning than the theory has explained because if a student waits for rewards before he/she would learn a language, then he/she will spend eternity to learn a language. Therefore, Wilkins (1972) believes that "carefully planned schedules of reinforcement are unnecessary since learning will take place whether or not the student is reinforced" (p. 172).

\section{B. Cognitive Theory}

Reacting to the behaviouristic approach, Chomsky (1959) declares that the theory is "at least incapable of explaining our ability to learn and use our mother tongue." To him, language is a complex rule-governed system, which emanates from the innate property (Wilkins, 1972) of a learner to learn a language. Chomsky (1966) refers to the innate knowledge as Language Acquisition Device (LAD). Essentially, according to Wilkins (1972), the theory holds that:

...everybody learns a language, not because they are subjected to a similar conditioning process, but because they possess an inborn capacity which permits them to acquire a language as a normal maturational process" (p. 168)

The cognitive or mentalist theory holds that learning is socially-oriented. The LAD features the power to distinguish one speech sounds from the other, organize and classify linguistic events, filters the possible linguistic system from the impossible ones, and the ability to select data with constant evaluation. By this, the learner would become competent in the knowledge of the grammar of the language (Harmer, 1983). To Cognitivists, therefore, language learning is a function of appropriate usage of the data processed by the brain through the senses. The theory, therefore, submits that language learning is a mental process (Bell, 1981; Titone \& Danesi, 1985).

However, critics of this theory held that language learning could not be divorced from the social environment. More so, no one can learn to speak if there is no one around; thus, language acquisition is a function of learn-by-doing. It would be difficult to subscribe to the submission of the idea that "the social factors have virtually no role at all" (Wilkins, 1972) in language learning.

\section{Humanistic Theory}

Humanistic theory, influenced by Rogers (1961), is another approach to language learning. From this point of view, language learning should be interpersonal and student-oriented following integrated and eclectic methodologies. The proponent maintains that the learner's personality is vital in the learning-teaching process, whereby an interpersonal relationship is established between the learner and the teacher. In all, Titone \& Danesi (1985) conclude that:

...some language learning tasks may require a behaviouristic approach (e.g., articulation); others, a more cognitive one (e.g., word order); still others may require an interpersonal approach (e.g., free speech exercises (p. 60).

However, since none of these theories seemed to adequately provide a clue to language learning, several other theories of language learning have since emerged as the offshoot of the trio - behaviouristic, cognitive and humanistic theories of language.

\section{Habit Formation Theory}

This theory holds that learning is a function of habit formation. It is patterned after Skinner's (1957) behaviouristic approach, which accounted for learning through the conditioning of the mind, formed as a result of consistent stimulus, responses, and reinforcements through reward. It followed the audio-lingual and audio-visual teaching methods of the nineteenth century, which focused on provisions of the receptive and productive skills of listening experience followed by speaking; and reading experience followed by writing. The approach was informed by automatic responses to linguistic stimuli, such as mimicry, memorization, and structural drilling, which were expected to impart "native-like" ability. In this regard, communicative and learning systems were synthetic rather than authentic, and strictly teacherinfluenced. The learning system was constructed totally to the teacher's perception of the learner's needs.

\section{E. Intellectual Capacity and Logic Theory}

This theory emphasizes the capacity of the learner to reason. It was rooted in Chomsky's (1959) cognitive or 'mentalistic' theory and explained by Rivers (1988) that:

...human beings come into the world with innate language learning abilities in the form of a language acquisition device (LAD) which proceeds (to acquire language through) by hypothesis testing...Language is thus rule-governed behaviour which enables speakers to create their utterances which conform to the rules they have internalized (p. 77) 
Contrary to the concept of passivism in the habit formation theory, the learning systems here allowed the learner's conscious and active involvement in learning the language, consequent upon which Chomsky's idea of competence and performance is put to play.

The changes in linguistic theory till the 1970s saw a shift away from the study of language seen purely as a formal system towards the study of language as communication; a shift towards sociolinguistics, discourse analysis, semantics, speech act theory, and pragmatics. This had a major impact on language teaching, culminating in the so-called communicative approach to second language teaching, which was a reaction against the predominant formalistic view of language teaching. Its initial impact was on syllabus design. Wilkins (1976), influenced by Halliday's functional approach to language and Austin's speech acts, produced a notional syllabus that took the language teaching world by storm (Van der Walt, 1992).

\section{F. Learner Motivation Theory}

Harmer (1983) defines motivation as "...some kind of internal drive that encourages somebody to pursue a course of action." From the humanists' point of view, learner's mental state is of paramount importance in the concept of language learning. Studies (Krashen, 1982; Widdowson, 1984) have shown that factors such as the learner's personality, which include intellect, background, ability, goal, and motivation, are essential to the learning process.

The desire to satisfy the various needs of language learners has informed the diverse teaching theories, which shall be examined in the next section of the study.

\section{THEORIES OF LANGUAGE TEACHING}

According to Rivers (1986),

Emphases in language teaching tend to swing from a preference for one approach to a growing attraction to the other, as successive generations of teachers seek to correct any imbalance which may have developed from the particular preoccupations of their producers. The deemphasis or re-emphasis of one or the other of these approaches is basic to many of the controversies, switches and changes which sweep through the language teaching profession from year to year (p. 21)

Going by this assertion, various theories have been propounded for language teaching over the years. Parrotts (1993) remarks that teachers need:

...to take account of the ways in which their students are predisposed to learn and to recognize the range of different predispositions which may be found in most groups of learners (p. 1)

This study attempts to examine many of these theories with second language acquisition approaches to come up with some appropriate processes of teaching the English language in Nigeria.

\section{A. In the Beginning}

Mackey (1965) reports that some speakers of the Latin language claimed to have learned it without rules, but agreed that learning the rules had aided their fluency and proficiency in the use of the language. For over 2,000 years, the prescriptive approach to language teaching prevailed. It holds that a variety of language be accorded a higher value than others, and be imposed on the users of the language. The proponents of the prescriptive approach opine that appropriate rules with illustrative examples must guide the teaching of any language. On the other hand, the descriptive approach to language teaching cares less about standards but sees all forms of usage as equally reasonable and acceptable (Crystal, 2010). It encourages students to investigate language on a deeper level and enables them to see the language in real use, instead of teaching them isolated prescriptive rules. Nevertheless, the two approaches are essential in language teaching and learning since they satisfy the condition of acceptability and intelligibility. Over the years, methods of language teaching had continued to vary, and teachers had attempted to overcome the controversies that emerged from the earlier approaches of prescriptivism and descriptivism. To this end, Jaccobovtz (1974) comments:

...the development of language methods...swing from the active oral use of Latin in ancient and Medieval times to the learning by the rules...back to oral activity...back to grammar rules... and back again to the primacy speech in the Direct Method.

\section{B. The Twentieth-century Language Teaching Theories}

As teachers are enjoined to think critically towards several ways through which their students would understand whatever they teach, approaches to language have since changed whereby new theories, though related to the existing ones, have emerged.

\section{Traditional Grammar-based Theory}

This theory, as the oldest approach to L2 teaching (Mackey, 1965), is based on earlier grammars of classical languages like Latin and Greek and applied to some language that is sometimes inappropriate (Xia, 2014). The theory is rooted in the prescriptive approach, which emphasizes written language but neglected its oral form (that is, speaking skills). It reduces language to the grammatical system by emphasizing the memorisation of the prescribed rules of morphology, phonology, syntax, and grammar. The influence of this theory on language teaching informs a method 
referred to as the 'grammar translation' method. The method is employed in teaching L2 with the teacher as the absolute authority, while the students are only encumbered with writing down in detail whatever the teacher teaches them. Chastain (1976) informs that,

...it is a mixture of grammar and translation activities. So, learners are required to learn and memorize the rules of grammar deductively and in detail. Along with these rules, learners must memorize lists of vocabulary. Translation is used as a test of learners understanding of the rules of grammar and vocabulary. Learners must translate reading passages into and from the native language. It is also a common practice to ask learners to state the rules (p. 35).

The main emphasis is on the translation of the written form and the grammar aspect of the target language into the native language, as a result of which students of the target language lag behind in its spoken form or communicative aspect. A major defect of the grammar-translation method - reading more than training in speaking creates room for a new approach to language teaching.

\section{Structuralism}

As the name implies, it concerns itself with the teaching of the structure of a language. Rivers (1964) states that "the learners learn to manipulate structures to the point of automatic response to a language stimulus," which suggests that the theory is patterned after Skinner's operant conditioning. Contrary to traditional grammar, it gives credence to mastery of structures, speech, the formation of language habits, the teaching of one item of language per time, learner's and teacher's involvement. The theory gives room for all the students to participate in learning the language. Hence, no student is left behind. For example, each student, as a matter of habit, first listens to the teacher, then speaks to repeat he/she has learned, then writes it down, after which he/she reads out. It implies that all the communication skills are deployed into the structuralists' teaching approach. It is not Greek or Latin-inclined; hence, it is more scientific than traditional grammar. No doubt, the theory is of great benefit to both teachers and learners of L2. However, the approach seems to be cumbersome as it requires a lot of practice, which might present the process as too mechanical and wearisome. The weakness in the structuralist approach invariably led to Chomsky's transformational generative grammar theory.

\section{E. Transformational Generative Grammar Theory}

The Transformational Generative Grammar (TGG) theory holds that competence in a language is innate as a result of the language acquisition device (LAD), which is inborn and could be developed through correct and suitable practice. The LAD is said to consist of a hypothesis-maker, linguistic universal, and an evaluation procedure. The proponent of the theory emphasises that it does not require explicit teaching for a child to learn or acquire his/her mother tongue, and the child progressively attains competence even in sentences that are not familiar to him/her. Further, according to TGG, in contrary to structuralists' approach, "a system of rules that in some explicit and well-defined way assigns structural descriptions to sentences" (Hu \& Wangqi, 2002). The theory probes into the discovery of underlying meaning, which is deeper than the surface structures of a language. Chomsky (1957) explains that the concept of language as the medium of meaning communication goes beyond the analysis of the syntactic features. However, the theory generates a lot of controversies, emphasizing that the position of the theory on language competence is not convincing enough to give interpretation to the concept of language.

\section{F. Audio-lingual Theory}

The theory evolved from the descriptive and behaviouristic approaches. It, therefore, encompasses the concepts of linguistic patterns and habit formation. The approach has its roots in language patterns and psychological theory (Brown, 1994) as well as the direct method. Its primary goal was to create communicative competence in its learners; hence, it focuses on the development of the native-like ability in them. It is audio-lingual because it encourages the use of tapes, language laboratories, and visual aids. The theory depended much on dialogue memorization of phrases, mimicry, pattern and repetitive drills, pronunciation, with a considerable effort to produce error-free speeches. This aims at conveying the linguistic systems of the target language on the premise of the insight from the structural linguists into the minds of the students in a manner that feedback would become spontaneous and customary. However, a critical examination of the audio-lingual theory created a room for language manipulation and neglect of content.

\section{G. Functional-notional Theory}

The theory assumes that a language is a tool for conveying meaning in an appropriate matter that suits the context of use. Earlier theories had concentrated on grammatical rules and emphasised the need to teach the whole spectrum of grammar. Still, the functional-notional theory is concerned with the specific and relevant functions that language is meant to perform within the contextual needs practically. The theory, therefore, holds the view that the language learner is exposed to services of the language used in real life so that it becomes easier for him/her to engage in the everyday language activities. To this end, teaching linguistic forms is essential. Still, it is more important to show the learner to be conversant with the various linguistic functions in daily use and have the knowledge of diverse contexts in which they are used (Xia, 2014, p.563).

\section{H. Natural Theory}


The Natural Approach to second language teaching was developed by Krashen and Terrell (1983) in the early eighties. The theory focuses on meaning rather than form; hence, except the learner engages in errors that may affect the meaning, correction is withheld during oral communication. Like the Direct approach, the learning process is not interrupted by the teacher, and the teacher uses the target language to communicate from the onset. However, it allows learners to use their MT alongside the TL during the learning process. The theory also subscribes more to language acquisition than language processing, so a lot of input is expected from the teacher. It is believed that the notion of advocacy for a 'silent period' to wait for vocal production to 'emerge' at its own stipulated time was the new effort to create an "expansive and overall approach" instead of a "specific method." However, the critics of the Natural theory believed that it would be challenging for the teacher to manage the classroom except he/she is highly skilled. Many of the criticisms led to another communicative approach.

\section{Communicative Theory}

Littlewood (1981) describes the communicative theory as a language teaching approach that "pays systematic attention to functional as well as structural aspects of language, combining these into a more fully communicative view." Canale (1983) further explains that the dominant principles of the theory of communicative competence involve an "unpredictable and creative social interaction which occurs in discourse that has socio-cultural context." The approach features the two parts or aspects of the language to teach and how to teach them. Here, the teacher teaches linguistic features, meanings, and functions and how to apply them in real communication in real life. The learner is inspired to communicate in the target language, for instance, to write an application letter, etc. The theory is authentic rather synthetic, as the teacher shall not interrupt the process. Canale and Swain (1980) also state that the teaching theory comprises the grammatical, sociolinguistic discourse, and strategic competence. It also consists of the identification of the learner's communication needs, learner's interests in the L2 system; the provision of realistic and meaningful communicative competence, as well as the provision of adequate information and practice of the experience required in L2 situations.

However, as much as the grammar would enable the learner to understand the fundamental instruments for using and practicing the language, communication would also provide the best opportunity for the learner to produce in spoken form the rules he/she has learned. In essence, both are essential in realistic contexts. The communicative theory is said to be the most scientific of all the language teaching theories. However, it cannot be said to be a perfect approach (Xia, 2014).

\section{J. Eclectic Theory}

Eclectic theory, also known as the active or compromise method due to its heterogeneity, was propounded to bridge the gap between the existing approaches to language teaching. Expounding on this observation, Yardi (1994) submits that

...this method makes use of the learner's mother tongue when necessary, accommodates teaching of formal grammar, makes use of situations for presenting teaching material and freely uses audio-visual aids.

Consequently, the theory involved the oral practice of sounds, reading aloud, the use of questions and answers in the target language to test their comprehension of the spoken form. It also visualized tests to check the understanding of the students, trained them in the use of vocabulary, and explained grammar deductively. In essence, the theory advocates the blending or combination of the best techniques in the language teaching theories for effectiveness and effectiveness.

It is on this basis that the present study seeks to do an overview of language teaching methods for the English language in Nigeria.

\section{Methods of TeACHING ENGLISH}

Different teaching methods are premised on or derived from the various language theories of teaching or learning processes enumerated earlier in this study. Each method has a different focus or priority in practical terms in the classroom. The principal methodologies are listed below in sequential order of their formation in time (as cited in Taylor, 2020):

1. Grammar Translation Method- the classical method

2. Direct Method - discovering the importance of speaking

3. Audio-lingual Method - the first modern methodology

4. Humanistic Approaches - a range of holistic methods applied to language learning

5. Communicative Language Teaching - the current standard method

6. Principled Eclecticism - fitting the method to the learner, not the learner to the method (Taylor, 2020).

The table of traditional and evolving language teaching methods with their focal points and characteristics designed and presented by Alex Taylor of TJ Taylor (an academic outfit) is adapted and presented thus: 


\begin{tabular}{|c|c|c|c|}
\hline & Methods & Focal Points & Characteristics \\
\hline 1. & Grammar Translation & Written literary texts & $\begin{array}{l}\text { (i)Translates from English into learners' } \\
\text { native language } \\
\text { (ii)It revolves around topics considered } \\
\text { useful for learners } \\
\text { (iii)Learners are made to learn the } \\
\text { grammar and vocabulary teachers think they } \\
\text { need to know }\end{array}$ \\
\hline 2. & $\begin{array}{l}\text { Direct Method (also called Natural } \\
\text { Method) }\end{array}$ & Everyday spoken language & $\begin{array}{l}\text { Students learn by directly associating } \\
\text { meaning in English }\end{array}$ \\
\hline 3. & Audio-Lingual Method & Sentence and sound patterns & $\begin{array}{l}\text { Students listen and speak by pattern } \\
\text { practice in English only }\end{array}$ \\
\hline 4. & Cognitive Code Approach & Grammar rules & $\begin{array}{l}\text { Students deduce English grammar rules } \\
\text { and apply to the context }\end{array}$ \\
\hline 5. & \multicolumn{3}{|c|}{ Humanistic Approaches - 4 accepted examples: } \\
\hline & (i) The Silent Way & $\begin{array}{l}\text { Student interaction rather } \\
\text { than teacher }\end{array}$ & $\begin{array}{l}\text { Students are allowed to understand how } \\
\text { English works while the teacher is silent }\end{array}$ \\
\hline & (ii) Suggestopedia & $\begin{array}{l}\text { Meaningful texts and } \\
\text { vocabulary }\end{array}$ & $\begin{array}{l}\text { Students are put in a relaxed atmosphere, } \\
\text { with music to encourage subliminal learning }\end{array}$ \\
\hline & (iii) Community Language Learning & Student interaction & $\begin{array}{l}\text { Students are engaged in active interactions } \\
\text { for the understanding of English }\end{array}$ \\
\hline & $\begin{array}{l}\text { (iv) Comprehension Approach } \\
\text { (Natural Approach, the Learnables, and } \\
\text { Total Physical Response) }\end{array}$ & Listening comprehension & $\begin{array}{l}\text { English speaking by students is delayed } \\
\text { until students are ready; meanings are } \\
\text { clarified through actions and visuals }\end{array}$ \\
\hline 6. & Communicative Language Teaching & $\begin{array}{l}\text { Interaction, authentic } \\
\text { communication and negotiating } \\
\text { meaning }\end{array}$ & $\begin{array}{l}\text { Students are made to understand English } \\
\text { through active interactions such as role-plays, } \\
\text { games, etc }\end{array}$ \\
\hline 7. & $\begin{array}{l}\text { Content-based, Task-based, and } \\
\text { Participatory Approaches }\end{array}$ & $\begin{array}{l}\text { What is being communicated, } \\
\text { not the structure of English }\end{array}$ & $\begin{array}{l}\text { Teaching is content-based and relevant to } \\
\text { students' lives: topics, tasks, problem-solving }\end{array}$ \\
\hline 8. & $\begin{array}{l}\text { Learning Strategy Training, } \\
\text { Cooperative Learning, and Multiple } \\
\text { Intelligences }\end{array}$ & How to learn & $\begin{array}{c}\text { Students' different intellectual levels } \\
\text { determine learning strategies, cooperation }\end{array}$ \\
\hline
\end{tabular}

Fig 1: Language Teaching Methods. Culled from Techniques and Principles in Language Teaching (Oxford University Press)

\section{Teaching And Learning English as a Second Language (ESL) In Nigeria}

Several studies (Adebileje 2013, 2014, 2017) show that the majority of the ESL learners, most importantly, in public schools, cannot competently express themselves in English. But, it is not so in privately owned schools, which suggests that the method of teaching could be faulty in public schools. It is apparent that without communicative competence in English, opportunities for a better life remain elusive, and the poverty level of young graduates deepens abysmally despite being educated. One major cause of this incompetence is due to improper English language teaching by unqualified teachers (Opoola \& Fatiloro, 2014). If it is not well taught, it certainly cannot be correctly learnt and competently used by learners. For many years now, results of secondary school students in English in public examinations such as West African School Certificate Examination (WASCE) and Nigeria Examination Council 
(NECO) have been persistently poor (Ogundele, Olanipekun, \& Aina, 2014). It is, therefore, necessary to carry out a study on the theories and methods of teaching and learning English for better results.

Notwithstanding, the teaching and learning of ESL can be very problematic, especially when the first language sounds are similar to English sounds but used in different contexts (Young, 1996). Also, there is more to learning English than vocabulary and grammar (Cummins, 1979, 1980, 1981; Snow, 1992). Also, learners' social background of their mother tongue, which is always complex, presents challenges to proficiency and easy comprehension of the English language. In corroboration, Cummins (1979) believes that children learning a second language have a communicative competence barrier. To this end, Robert (1964) states:

A person knows to use a language when he can use its structure accurately for communication, with attention focused on the content, recalling automatically the units and patterns as needed, and holding them for a normal memory span at conversational speed, noticing any errors that occur.

It takes a lot of skillful teaching for English learners to reach this level of competence as explained by Robert. As a result of the learners' problems enumerated above, learners are unsure of the target language functions as well as the correctness of language usage within specific contexts (Xu \& Drame, 2008). Therefore, both teachers and learners could get stressed and frustrated with these types of challenges (Gillanders, 2007).

\section{A. What Is the Best Teaching Method for Learning English?}

Linguists are of the opinion that there is not one single best method for all learners in all contexts and that no one teaching method is inherently better than the others (nankonyo.blogspot.com). Besides, the application of the same teaching methods to all learners with different levels of understanding of the language is not appropriate and effective. For greater effectiveness, language teachers are expected to apply the most proper methods to take care of learners' needs. Depending on the most suitable techniques, a trained language teacher is expected to adopt a principled eclecticism approach that will address learners' specific objectives and needs. Hence, in the last four to three decades, methods of teaching English have evolved in order to solve some language teaching problems. Based on the existing language teaching and learning theories, the study, finally, suggests some modern approaches for teaching and learning the English language in Nigeria as recommended by Fluentu, 2020.

\section{B. Task-based Approach}

The task-based approach as described by fluentu.com is the direct opposite of the traditional curriculum design. It signifies a significant paradigm shift from focusing on content to emphasizing skills and competencies. So, planning and design are not about what is taught, but why it is taught (www.fluentu.com). This approach according to (fluentu.com) isolates individual skills and competencies to explain the areas or aspects students need to know to meet their goals and objectives. The task-based method involves more of students' input as they feel comfortable with what they are involved in and can relate with. Instances in the day to day activities of learners that could be regarded as taskbased and used for teaching include placing an order in a restaurant, requesting a hotel room, or perhaps more advanced tasks like reviewing a movie or voicing their opinions about politics (Fluentu.com). In this approach, the language taught revolves around the task itself, not the other way around. For this method to work, teachers must understand their students' needs and expectations in order to design lessons that help their students succeed (www.fluentu.com). There is a need for teachers to ask the question, "Why are my students learning English?" Teachers must then look at ways to help their learners achieve their personal and/or professional goals. The answers to these questions will help language teachers create a teaching plan that is relevant to students' needs (www.fluentu.com).

\section{Project-based Approach}

Much like the task-based approach, the project-based approach is meant to address students' real needs by adapting language to the skills and competencies they truly need personally and professionally (www.fluentu.com). The application of this approach begins by determining the one global objective that the individual or group of students have. This can be achieved by doing a need-assessment, such as looking at what learners are interested in and what topics they really need to know. This assessment will lead to the design of one overarching project that will become the end result of the class, term, or course. The project can be anything from an oral presentation to a large-scale production, such as a class play. Whatever the case, the plan must comprise individual tasks that lead students to the goals in the assessment (www.fluentu.com).

\section{Lexical Syllabus Approach}

While the previous two approaches focus heavily on the skills and competencies that learners need to develop, this approach focuses on content and what language they actually need to produce (Fluentu, 2020). In particular, the actual words that students need to understand in order to conduct specific tasks are the focus of the class. This approach is based upon the core language that students need to know according to their needs. Also, professional students need precise vocabulary used by different disciplines and professions, that is, register.

\section{E. Use of Technology Approach}

At this tech age, many readily available aids can be used in the classroom to enhance teaching and learning. 
Smartphones, for example, have become a part of modern life. Since just about everyone has internet access or data plan, school authorities could take advantage of smartphones as a useful teaching tool instead of seeing them as a distraction. Both teachers and learners can be creative with the use of smartphones. For instance, smartphones provide many useful tools for students, such as a dictionary, translator, and grammar reference apps. Much like computers, students need to understand that their phones are not for play or personal use, but to be used as learning tools. Aside from translations, Word Reference is an app that has a thesaurus, an English dictionary, and a forum where other users can comment on difficult words or expressions. Learners can be asked to browse through websites to find the information they need to write essays or complete some write-ups. Students can also use their devices to access free, online exercises that reinforce language and skills seen in class. Other uses can involve students recording their activities (sourced from https://www.fluentu.com/blog/educator-english/new-methods-of-teaching-english/).

While traditional approaches do provide a solid foundation for effective language teaching, they do not always address students' current needs. The task-based approach focuses on the skills and competencies students need. The project-based approach builds on the task-based approach using specialized activities. The lexical syllabus provides students with the content they will need in different linguistic situations. All these approaches, combined with the effective use of technology in the classroom will result in an engaging technique that cannot be ignored.

\section{CONCLUSION}

Adebileje (2014) submits that a competent user of a language should exhibit the four skills of speaking, writing, listening, and reading competently. Therefore, it suffices to assert that only one method or approach will not provide this competence in a learner. Grammar, vocabulary, and language skills are just the vehicles that enable students to achieve their outcomes.

Thus, this study has critically examined different theories of language teaching and learning, which include behaviouristic, cognitive, humanistic, habit formation, intellectual capacity, and learner motivation learning theories. The teaching theories examined include formal and functional, traditional grammar-based, structuralism, transformational generative grammar, audio-lingual, functional-notional, direct method, natural, communicative, and eclectic theories. of use. It also establishes that none of the theories is perfect in all situations. It, therefore, becomes expedient to identify, select the best techniques in the theories, and blend them to suit the students' needs to achieve the desired results.

In conclusion, for practical and engaging classes, teachers are encouraged to consider the following teaching processes:

(1) be familiar with the backgrounds of the students;

(2) design the teaching style in line with the students' needs and context;

(3) use a variety of approaches to achieve the best result in the course of teaching;

(4) involve the students directly in conversation activities;

(5) make use of different techniques, such as critical thinking, debates, etc.

(6) use audio-oral and audio-visual aids (e.g., video clips, tapes, etc.) in which native speakers of English are involved in conversations'

(7) engage students in humorous events, such as jokes, problem-solving adventures, etc.

(8) encourage students to read texts and materials in class;

(9) encourage students to interact with speakers of English;

(10) do not be too critical, too much correction can be counterproductive; and

(11) learn to tolerate errors that are not likely to cause meaning change.

It is suggested that learners could also consider the following learning processes for a more fulfilling class:

(1) build up skills that improve personal learning and self-assessment;

(2) learn through visual, audio, and kinesthetic media;

(3) sit where the teacher can be seen and heard;

(5) take numerous detailed notes;

(6) consider errors as a necessary aspect of learning; and

(7) ready to be corrected.

\section{REFERENCES}

[1] Adebileje, A.O. (2013). Syntactic Errors of Nigerian Undergraduates in English: The Role of the First Language (L1) and Pedagogical Implications. International Journal of Science Commerce and Humanities. 1(1), 93-105.

[2] Adebileje, A. (2014). 'Communication and study skills'. In F. Akere, A. Adebileje \& Unuabonah, F. (eds.) Use of English I \& II. Ede: Directorate of General Studies Programme Redeemer's University, 1-14.

[3] Adebileje, A.O. (2017). Analysis of elements of Africanism in the Nigerian linguistic landscape. International Journal of Linguistics and Communication. 5(1), 35-43. 
[4] Adetugbo, A. (1984). The development of English Language in Nigeria up to 1914: A sociohistorical appraisal. Journal of the Historical Society of Nigeria, 9(2), 89-105.

[5] Akindele, F. \& Adegbite, W. (2005). The Sociology and politics of English language in Nigeria: An introduction. Ile-Ife: Obafemi Awolowo University Press.

[6] Alex Taylor. (2020). Language Teaching Methods. Techniques and Principles in Language Teaching. Oxford University Press. TJ Taylor.

[7] Asiyanbola, A. A. (2013). Basic English Grammar for Universities: An introduction. (Revised Ed.). Lagos: Olivetree Publishing Venture.

[8] Awonusi, V. O. 2009. 'Some characteristics of Nigerian English phonology.' In A. B. K. Dadzie \& V. Awonusi (eds.), Nigerian English: Influences and characteristics. Lagos: Concept Publication, 203-241.

[9] Aziza, O. (1998). 'Nigerian language and national development. In R. Druhonmalase (ed.) Nigerian language for national development. Ibadan: University Press.

[10] Banjo, A. (2016). Making a virtue of necessity: An overview of the English language in Nigeria (New. Ed.). Ibadan: Ibadan University Press.

[11] Bell, R. T. (1981). An introduction to Applied Linguistics. London: B. T. Batsford Ltd.

[12] Belyayev, F. (1972). The teaching of foreign language. NY: Random House.

[13] Brown, H. D. (1994). Teaching by principles: An interactive approach to language pedagogy. Prentice-Hall. Regents.

[14] Canale, M. (1983). "From communicative competence to communicative language pedagogy." In Richards, J. \& R. Schmidt (eds.) Language and communication. London: Longman.

[15] Canale, M. \& Swain, M. (1980). Theoretical bases of communicative approaches to second language teaching and testing. Applied Linguistics, 1, 1-47

[16] Chastain, R. (1976). Developing second language skills. Chicago: Random Mc MA.

[17] Chomsky, A. N. (1957). Syntactic structures. The Hague: Mouton.

[18] Chomsky, A. N. (1959). A review of language behaviour. The Hague: Mouton.

[19] Chomsky, A. N. (1966). Cartesian Linguistics, New York: Harper and Row.

[20] Cummins, J. (1979). Cognitive/academic language proficiency, linguistic interdependence, the optimum age question and some other matters. Working Papers on Bilingualism, 19, 121-129.

[21] Cummins, J. (1980). Psychological assessment of immigrant children: Logic or intuition? Journal of Multilingual and Multicultural Development, 1, 97-111.

[22] Cummins, J. (1981). Age on arrival and immigrant second language learning in Canada: A reassessment. Applied Linguistics, 1, 132-149.

[23] Crystal, D. (2010). The Cambridge encyclopedia of language ( $3^{\text {rd }}$ Ed.). Cambridge: Cambridge University Press.

[24] Dulay, H. \& Burt, M. K. (1974). Errors and strategies in child second language acquisition. TESOL, 8(2), 129-136.

[25] English for all: Long life education (2018). nankonyo.blogspot.com

[26] Fatunsin, S. A. (2007). An introduction to the phonetics and phonology of English (2 ${ }^{\text {nd }}$ Ed.). Greenfield, Lagos.

[27] Fluentu (2020). 4 New Methods of Teaching English in the Modern Classroom. https://www.fluentu.com/blog/educatorenglish/new-methods-of-teaching-english/.

[28] Gumperz, J. J. (1962). Types of lingual communities. Anthropological Linguistics. 4, 28-40.

[29] Gut, Urlike. (2004). 'Nigerian English Phonology'. In E. W. Schneider, K. Burridge, B. Kortmann, R. Mesthrie\& Upton, C. (eds.) A Handbook of Varieties of English Vol. 1: Phonology. NY: Mouton de Gruyter, 814-841.

[30] Gillanders, C. (2007). An English-speaking prekindergarten teacher for young Latino children: Implications of the teacherchild relationship on second language learning. Early Childhood Education Journal, 35(1), 47-54.

[31] Harmer, J. (1983). The practice of English language teaching. London: Longman.

[32] Howatt, A. (1984): A History of English Language Teaching. Oxford: Oxford University Press.

[33] $\mathrm{Hu}, \mathrm{Z}$. \&Wangqi, J. (2002). Advanced linguistics. Beijing, Peking UP.

[34] Jaccobovitz, L. (1974). The context of foreign language teaching. Rowley Mass: Newbury House.

[35] Krashen, S. D. (1987). Principles and practice in second language acquisition. Prentice-Hall Int., UK

[36] Krashen, S. D. \& Terrell (1983). The natural approach of language acquisition in classroom. Hayward, CA: The Alemany Press.

[37] Lado, R. (1964). Language teaching: A scientific approach. NY: McGrew Hill.

[38] Larsen-Freeman, D. \& Anderson, M. (2011). Techniques \& Principles in Language Teaching (3 ${ }^{\text {rd }}$ ed.). New York: Oxford University Press.

[39] Littlewood, W. (1981). Communicative language teaching: An introduction. Cambridge: Cambridge University Press.

[40] Mackey, W. F. (1965). Language teaching analysis. London: Longman.

[41] Ogundele, G. A., Olanipekun, S. S. \& Aina, J. K. (2014). Causes of poor performance in West African School Certificate Examination (WASCE) in Nigeria. Scholars Journal of Arts, Humanities and Social Sciences, 2(5B), 670-676.

[42] Opoola B.T \& Fatiloro, O. F. (2014). On Communicative Competence and Students' Performance in English Language. The International Journal of Engineering and Science (IJES). 3(8), 65-68.

[43] Palmer, H. E. (1964). The principles of language study. London: Oxford University, Press

[44] Palmer, H. E. (1969). The scientific study and teaching of language. London: Oxford University, Press.

[45] Lightbown, P. \& Spada, N. (1993). How languages are learned (4 ${ }^{\text {th }}$ ed.). Oxford: Oxford University Press.

[46] Richards \& Rodgers, T. S. (1988). Approaches and methods in teaching: A description analysis. Cambridge: Cambridge University Press.

[47] Rivers, W. (1964): The Psychologist and the Foreign Language Teacher. Chicago and London: University of Chicago Press

[48] Rivers, W. M. (1970). Teaching foreign language skills. Chicago: Chicago University Publication.

[49] Sapir, E (1921). Language. New York: Harcourt Brace.

[50] Skinner, B. F. (1957). Verbal behaviour. New York: Appleton-Century Crofts.

[51] Swain, M. (1985a). A critical look at the communicative approach (1). English Language Teaching Journal. 39(1) 2-12. 
[52] Swain, M. (1985b). "Large-scale communicative language testing: A case study." In Lee, Y. P. et al. , (eds.) New directions in language testing. Oxford: Pergamon.

[53] Titone, B. \& Danesi, M. (1985). Applied psycholinguistics: An introduction to the psychology of language learning and teaching. Toronto: University of Toronto Press.

[54] Ugochi, I. C. (2016). Teachers' motivation for effective implementation of the National Language Policy in Ebonyi State, Nigeria. International Journal of Education, Learning and Development 4(2), 35-44.

[55] Van der Walt, J. L. (1992). Linguistic and second language teaching: An assessment. Stellenbosch Papers in Linguistics, 25, 169-182.

[56] Webster (1943). New International Dictionary. Oxford: Oxford University Press.

[57] Widdowson, H. G. (1990). Aspects of language teaching. Oxford: Oxford University Press.

[58] Wilkins, D. A. (1972). Linguistics in language teaching. London: Edward Arnold.

[59] Xia, Y. (2014). Language theories and language teaching - from traditional grammar to functionalism. Journal of Language Teaching and Research. 5(3), 559-565.

[60] Xu, Y. \& Drame, E. (2008). Culturally appropriate context: Unlocking the potential of response to intervention for English language learners. Early Childhood Education Journal. 35, 305-311.

[61] Yardi, V. V. (1994). Teaching English in India today ( $3^{\text {rd }}$ ed.). Aurangabad: Parimal Prakasha

[62] Young, K. S. (1996). Internet Addiction: The Emergence of a New Clinical Disorder. Cyber Psychology \& Behavior, 1, 237244.

Adebola Adebileje is a Professor of Applied English Linguistics. Her areas of interest are English as a Second Language, Nigerian English, English Syntax, Sociolinguistics, and Onomastics. She attended University of Ilorin, Ilorin, Nigeria where she had her BA (Ed) Eng, (1989), MEd Eng, (1995) and PhD (English Language Education) in 2002. Her research focus largely dwells on actual language use in which she compares and examines processes, patterns and structures (Syntax) among languages, especially, indigenous languages and the English Language; and identifying challenges in the actual use of language (English as a Second Language) by students, teachers and the Nigerian society (social influence) at large. Her current collaborative research, Diachronic Evolution of English in Nigeria is being sponsored by Redeemer's University, Ede, Nigeria. She is a member of the following Professional bodies, Nigerian English Studies Association (NESA) now English Scholars Association of Nigeria (ESAN); Linguistic Association of Nigeria (LAN); Reading Association of Nigeria (RAN); American Association of Applied Linguistics (AAAL); and Linguistic Society of America (LSA). She is the Vice President; Society for the Study of Names in Nigeria (SSNN). Professor Adebola Adebileje loves teaching and mentoring students. She strongly believes in teamwork for building a great and successful organisation. She is a Pastor in the Redeemed Christian Church of God and happily married to Pastor Olusegun Adebileje. They are both blessed with children and grand children.

Aderonke Oladunke Akinola was born in Akure, Nigeria and had her Master's degree in English Language, 2019 at the Redeemer's University, Ede, Osun State, Nigeria. She is presently a doctoral student in the Department of English in the same University. Her major field is Corpus Phonology with a special interest in Applied Linguistics. She lectures Phonetics and Phonology, The English Language in Nigeria, History of the English Language, Techniques of Writing and Spoken English at the Redeemer's University, Ede. She has published a paper with two others under peer-review in reputable journals. Her current research interest is Phonological study of Free Variation in Nigerian English. Mrs. Akinola is a member of the English Scholars' Association of Nigeria (ESAN), Association of Phoneticians and Phonologists in Nigeria (APPN) and a Fellow of Ife Institute of Advanced Studies (IIAS). 